\title{
The Enzymatic Activity of Type 1 Iodothyronine Deiodinase (D1) is Low in Liver Hemangioma: A Preliminary Study
}

\author{
Oskar Kornasiewicz • Marcin Debski • \\ Marta Stepnowska • Anna Szałas • \\ Ewa Bar-Andziak • Marek Krawczyk
}

Received: 1 August 2008/Accepted: 7 August 2009/Published online: 5 January 2010

(C) L. Hirszfeld Institute of Immunology and Experimental Therapy, Wroclaw, Poland 2009

\begin{abstract}
Type 1 iodothyronine deiodinase (D1) is a crucial enzyme which converts the prohormone thyroxine (T4) into active tri-iodothyronine (T3). There has been strong evidence that the metabolism of thyroid hormones is disturbed in some neoplastic tissues such as thyroid, renal, and breast cancer. However, there are few available data about D1 enzyme activity in benign tumors such as hemangioma, which is the most common primary liver tumor. Hence this study aimed to determine the enzymatic activity of D1 in hemangiomas in relation to healthy liver tissue. Seven tumors and healthy control tissues were obtained from patients who had liver resection due to hemangioma. The activity was assessed by measurement of radioactive iodine released by deiodination catalyzed by D1. It was found that D1 activity was significantly lower in the hemagiomas than in the healthy surrounding tissue $(p=0.0017)$. The results indicated that thyroid hormones play important roles not only in the regulation of cell metabolism, but also in cell growth, division, and apoptosis. The active form T3 acts through its nuclear receptors and influences the up- and down-regulation of target genes. Healthy liver tissue expresses a high level of D1, but disturbed D1 activity may result in changes in the local concentration of T3 which may impair gene transcription. These finding demonstrate a low enzymatic activity of D1 in liver hemangioma and suggest an
\end{abstract}

O. Kornasiewicz $(\bowtie) \cdot$ M. Krawczyk

Department of General, Transplant, and Liver Surgery,

Warsaw Medical University, Banacha 1A,

02-097 Warsaw, Poland

e-mail: oskar.kornasiewicz@gmail.com; oskorn@o2.pl

M. Debski - M. Stepnowska - A. Szałas · E. Bar-Andziak Department of Internal Medicine and Endocrinology, Warsaw Medical University, Warsaw, Poland as yet unknown role of thyroid hormones in this type of benign liver tumor.

Keywords Hemangioma - Liver resection · Iodothyronine deiodinase (D1)

\section{Introduction}

The role of thyroid hormones in carcinogenesis has been postulated for many years. However, existing data are not sufficient for a complete understanding of the process. Thyroxin (T4), which is the main product of the thyroid gland, is considered a pro-hormone and must be converted to the active form, tri-iodothyronine (T3). T3 acts through its nuclear receptors, i.e., thyroid hormone receptors (TRs), and has significant influence on transcription, translation, and cell division and differentiation. T3 is produced by monodeiodination catalyzed by type 1 iodothyronine deiodinase (D1). This enzyme is present in almost all human cells, but the highest concentrations were found in the thyroid, liver, and kidneys (Bianco et al. 2002). Both its enzymatic activity and its gene expression have been examined in some cancers tissues. Significant decreases in gene expression and enzyme activity were found in papillary thyroid cancer tissue (Ambroziak et al. 2005; De Souza Meyer et al. 2005) as well as in papillary and follicular thyroid cancer cell lines (Arnaldi et al. 2005; Schreck et al. 1994), renal clear cell cancer (Pachucki et al. 2001), lung cancer (Wawrzynska et al. 2003), and pituitary adenomas (Baur et al. 2002; Tannahill et al. 2002). Surprisingly, elevated D1 enzyme activity and mRNA expression were described in human breast cancer tissue (Debski et al. 2007; García-Solís and Aceves 2003). 
There has been strong evidence that the metabolism of thyroid hormones is disturbed in some of neoplastic tissues (Gonzalez-Sancho et al. 2003; Jakobs et al. 2002). However, there are few available data about D1's enzymatic activity in benign tumors such as hemangiomas, which are the most common primary liver tumors. Interestingly, in this type of benign lesion an elevated level of deiodinase type 3 (D3), which inactivates thyroid hormones, was reported (Ho et al. 2005; Huang et al. 2005; Konrad et al. 2003).

The aim of this study was to determine the enzymatic activity of D1 in liver hemangioma in comparison with healthy liver tissue.

\section{Materials and Methods}

Seven tumor samples and an equal number of healthy liver control samples were obtained from patients who underwent liver resection for hemangioma, which is now a very rare indication for surgical intervention. Liver resection is limited to a very selected group of patients. There were neither postoperative deaths nor major complications. The group consisted of three men and four women with a mean age of 50 years. Five patients had extended liver resection (more than three segments). In two cases the resection included two segments. The mean tumor size was $7.86 \mathrm{~cm}$ (Table 1). The samples were taken from the tumor as well as from a site far from it, which was macroscopically normal liver tissue. These noncancerous tissues were assigned as controls. Immediately after the surgical procedures, the samples were frozen in carbon dioxide snow and kept at $-70^{\circ} \mathrm{C}$ until needed. In addition, a blood sample for thyroid hormone determination (TSH, fT3, and fT4) was taken from each patient before the operation. The results were within the normal ranges (Table 2).

The tissue samples were thawed and then homogenized in homogenization buffer (0.1 M PE [K2HPO4/KH2PO4],

Table 1 Demographic data and tumor characteristics

\begin{tabular}{lllcl}
\hline $\begin{array}{l}\text { Patient } \\
\text { number }\end{array}$ & Sex & Age & $\begin{array}{l}\text { Tumor } \\
(\mathrm{cm})\end{array}$ & Histopathology \\
\hline 1 & F & 50 & 8 & Hemangioma \\
2 & M & 64 & 5 & Hemangioma \\
3 & F & 61 & 6 & Hemangioma \\
4 & F & 41 & 10 & Hemangioma \\
5 & F & 40 & 12 & Hemangioma \\
6 & M & 56 & 10 & Hemangioma \\
7 & M & 38 & 4 & Hemangioma \\
& Mean & 50 & 7.86 & \\
\hline
\end{tabular}

Table 2 Summary of thyroid hormone results (TSH, fT3, and fT4)

\begin{tabular}{llll}
\hline $\begin{array}{l}\text { Patient } \\
\text { number }\end{array}$ & $\begin{array}{l}\text { TSH } \\
(0.27-4.2 \mu \mathrm{I} \mathrm{U} / \mathrm{ml})\end{array}$ & $\begin{array}{l}\mathrm{fT} 4 \\
(12-22 \mathrm{pmom} / \mathrm{l})\end{array}$ & $\begin{array}{l}\mathrm{fT} 3 \\
(3.1-6.8 \mathrm{pmol} / \mathrm{l})\end{array}$ \\
\hline 1 & 0.731 & 19.9 & 4.8 \\
2 & 1.850 & 16.5 & 4.8 \\
3 & 1.430 & 15.6 & 4.9 \\
4 & 3.610 & 16.7 & 4.8 \\
5 & 0.822 & 16.9 & 4.4 \\
6 & 0.334 & 14.3 & 4.1 \\
7 & 0.983 & 17.6 & 4.7 \\
\hline
\end{tabular}

$1 \mathrm{mM}$ EDTA, $10 \mathrm{mM}$ DTT-dithiothreitol, and $0.25 \mathrm{M}$ sucrose, $\mathrm{dH}_{2} \mathrm{O}, \mathrm{pH}$ 7.0). Protein concentration was measured by the BCA (bicinchonic acid) method using bovine albumin as the standard.

D1 activity was measured by quantification of radioactive iodide released from $3^{\prime} 5^{\prime}\left[{ }^{125} \mathrm{I}\right]-\mathrm{rT} 3$, which was purified by Sephadex LH20 column chromatography just before each assay. It was washed out with $10 \mathrm{ml}$ of $\mathrm{H}_{2} \mathrm{O}$ followed by elution with $2 \mathrm{ml}$ of $75 \%$ ethanol in $0.5-\mathrm{ml}$ fractions (this amount of $75 \%$ alcohol did not affect the reaction). We used fractions with the highest activity $(50,000-60,000$ CMP-counts per minutes) and added $70 \mu \mathrm{l}$ into each reaction tube.

The samples were incubated for $30 \mathrm{~min}$ at $37^{\circ} \mathrm{C}$ in phosphate buffer (0.1 M PE and $1 \mathrm{mM}$ EDTA, pH 6.9) with $1 \mathrm{nM}$ unlabeled rT3 and $10 \mathrm{mM}$ DTT. Each assay was performed twice and there was always one extra sample with propylthiouracyl added to show the inhibition of D1 by this agent. After incubation, the reaction was stopped by placing the samples in an ice bath. Precipitation was then caused by adding $100 \mu \mathrm{l}$ of horse serum and $50 \mu \mathrm{l}$ of $50 \%$ trichloroacetic acid. The samples were vortex for $1.5 \mathrm{~min}$ and centrifuged at 9,000 rpm for $5 \mathrm{~min}$. An aliquot of the supernatant containing ${ }^{125} \mathrm{I}$, but not labeled iodothyronines, was counted in a gamma counter (Wzard-1470, Wallac). Final enzymatic activity was expressed as the fmol of released ${ }^{125} \mathrm{I}$ per $\mathrm{mg}$ of protein per minute. The STATISTICA program was used for the statistical analysis.

\section{Results}

As this was a preliminary study only, seven tissue samples were examined. The median value of D1 enzyme activity in the tumor tissue was $32 \mathrm{fmol} /(\mathrm{mg}$-protein $\mathrm{min}$ ) (range: $0-132)$. The median value of its enzymatic activity in the healthy control samples was $549 \mathrm{fmol} /(\mathrm{mg}$-protein min) (range: 244-1243). D1 activity was significantly lower in the hemagiomas than in the healthy liver samples $(p<0.0017$; Figs. 1, 2). 


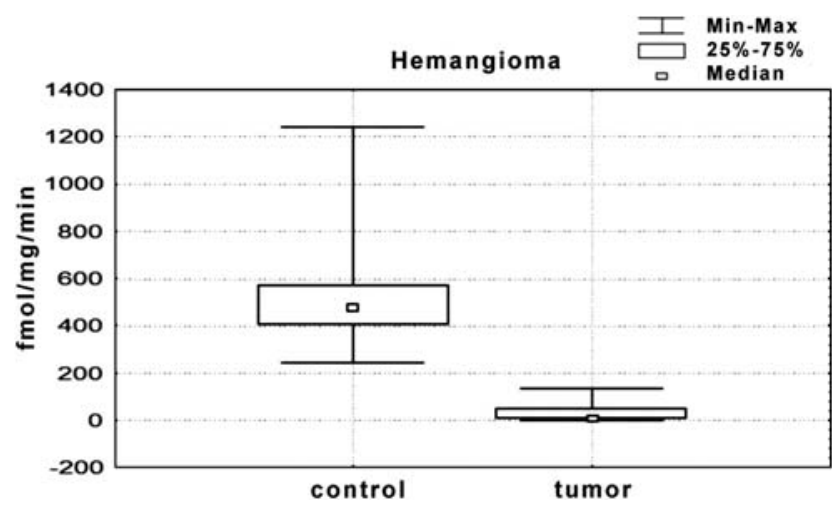

Fig. 1 Comparison of D1 activity in hemangioma and surrounding normal liver (control)

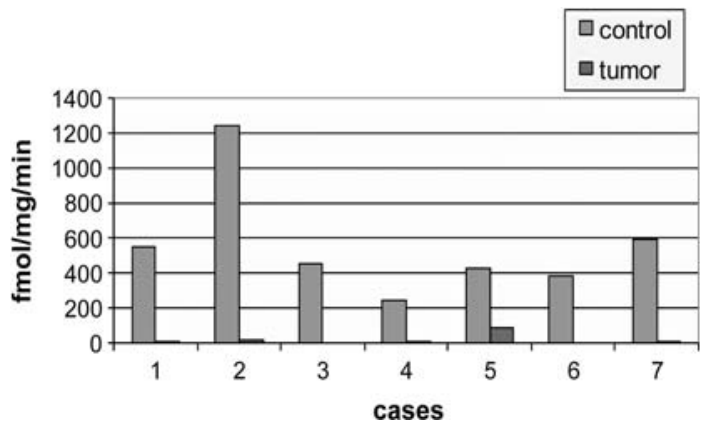

Fig. 2 D1 activity in each of the seven cases

\section{Discussion}

The presented data showed very low, almost undetectable, activity of D1 in 6 of the 7 investigated hemangioma tissue samples, especially in comparison with healthy liver tissue, which was thought to be responsible for ca. $70 \%$ of the peripheral activation of T4 (Macke-Nauman 1990). However, more recent data suggest that more T3 may be produced by D2 deiodination, which takes place in skeletal muscle as well as in liver tissue (Maia et al. 2005; Salvatore et al. 1996). This result could be associated with the differences in hemangioma and healthy liver tissue morphology. The largest part of the tumor develops from endothelial cells derived from epithelium, not hepatocytes. It was demonstrated that there is a high prevalence of the major physiological inactivator of thyroid hormones, D3, in the epithelium, which causes results opposite to those of D1 (Huang 2005; Huang et al. 2003; Zhang et al. 2006). The effect of D3 could appear as a very low concentration of thyroid hormones in the lesion, but there is no strong evidence concerning this occurrence. It seems reasonable to investigate rT3 and fT3 concentration in situ as next part of our studies.

It was also observed that the rapid resolution of consumptive hypothyroidism in children with multiple hepatic hemangiomas is a result of the high enzymatic activity of D3 and the production of TSH-like hormone by the tumor tissue. Children who required high doses of thyroid hormones were cured following liver transplantation, which proves the positive correlation between D3 enzyme activity in hemangiomas and hypothyroidism. Isolated incidents were also noted in adults (Ho et al. 2005; Huang et al. 2005; Konrad et al. 2003).

In conclusion, thyroid hormones play important roles not only in the regulation of cell metabolism, but also in cell growth, division, and apoptosis. The active form T3 acts through its nuclear receptors and influences the upand down-regulation of target genes. Disturbed activity of D1 may result in changes in the local concentration of T3. Furthermore, it may impair some gene transcription. Our finding clearly demonstrates a low enzymatic activity of D1 in liver hemangioma and suggests a so far unknown role of thyroid hormones in this type of liver tumor, which makes further investigation reasonable.

\section{References}

Ambroziak M, Pachucki J, Stachlewska-Nasfeter E et al (2005) Disturbed expression of type 1 and type 2 iodothyronine deiodinase as well as titf $1 / \mathrm{nkx} 2-1$ and pax-8 transcription factor genes in papillary thyroid cancer. Thyroid 15:1137-1146

Arnaldi LA, Borra RC, Maciel RM et al (2005) Gene expression profiles reveal that DCN, DIO1, and DIO2 are underexpressed in benign and malignant thyroid tumors. Thyroid 15:210-221

Baur A, Buchfelder M, Köhrle J (2002) Expression of 5'-deiodinase enzymes in normal pituitaries and in various human pituitary adenomas. Eur J Endocrinol 147:263-268

Bianco AC, Salvatore D, Gereben B et al (2002) Biochemistry, cellular and molecular biology, and physiological role of the iodothyronine selenodeiodinases. Endocr Rev 23:38-89

De Souza Meyer EL, Dora JM, Wagner MS et al (2005) Decreased type 1 iodothyronine deiodinase expression might be an early and discrete event in thyroid cell dedifferentation towards papillary carcinoma. Clin Endocrinol 62:672-678

Debski MG, Pachucki J, Ambroziak M et al (2007) Human breast cancer tissue expresses high level of type $15^{\prime}$-deiodinase. Thyroid 17:3-10

García-Solís P, Aceves C (2003) 5'Deiodinase in two breast cancer cell lines: effect of triiodothyronine, isoproterenol and retinoids. Mol Cell Endocrinol 201:25-31

Gonzalez-Sancho JM, Garcia V, Bonilla F et al (2003) Thyroid hormone receptors/THR genes in human cancer. Cancer Lett 192:121-132

Ho J, Kendrick V, Dewey D et al (2005) New insight into the pathophysiology of severe hypothyroidism in an infant with multiple hepatic hemangiomas. J Pediatr Endocrinol Metab 18:511-514

Huang SA (2005) Physiology and pathophysiology of type 3 deiodinase in humans. Thyroid 15:875-881

Huang SA, Dorfman DM, Genest DR (2003) Type 3 iodothyronine deiodinase is highly expressed in the human uteroplacental unit and in fetal epithelium. J Clin Endocrinol Metab 88: $1384-1388$ 
Huang SA, Mulcahey MA, Crescenzi A et al (2005) Transforming growth factor-beta promotes inactivation of extracellular thyroid hormones via transcriptional stimulation of type 3 iodothyronine deiodinase. Mol Endocrinol 19:3126-3136

Jakobs TC, Mentrup B, Schmutzler C et al (2002) Proinflammatory cytokines inhibit the expression and function of human type I $5^{\prime}$ deiodinase in HepG2 hepatocarcinoma cells. Eur J Endocrinol 146:559-566

Konrad D, Ellis G, Perlman K (2003) Spontaneous regression of severe acquired infantile hypothyroidism associated with multiple liver hemangiomas. Pediatrics 112(6 Pt 1):1424-1426

Macke-Nauman A (1990) Monodejodynacja tyroksyny do trijodotyroniny - specyficzność tkankowa. Regulacyjny wpływ katecholamin. Endokrynol Pol 41:4-54

Maia AL, Kim BW, Huang SA et al (2005) Type 2 iodotyronine deiodinase is the major source of plasma T3 in euthyroid humans. J Clin Invest 115:2524-2533

Pachucki J, Ambroziak M, Tański $Z$ et al (2001) Type $15^{\prime}$ iodothyronine deiodinase activity and mRNA are remarkably reduced in renal clear cell carcinoma. J Endocrinol Invest 24:253-261

Salvatore D, Bartha T, Harney JW et al (1996) Molecular biological and biochemical characterization of the human type 2 selenodeiodinase. Endocrinology 137:3308-3315

Schreck R, Schnieders F, Schmutzler C et al (1994) Retinoids stimulate type I iodothyronine $5^{\prime}$-deiodinase activity in human follicular thyroid carcinoma cell lines. J Clin Endocrinol Metab 79:791-798

Tannahill LA, Visser TJ, McCabe CJ et al (2002) Dysregulation of iodothyronine deiodinase enzyme expression and function in human pituitary tumours. Clin Endocrinol 56:735-743

Wawrzynska L, Sakowicz A, Rudzinski P et al (2003) The conversion of thyroxine to triiodothyronine in the lung: comparison of activity of type I iodothyronine $5^{\prime}$ deiodinase in lung cancer with peripheral lung tissues. Monaldi Arch Chest Dis 59:140-145

Zhang WJ, Ye LY, Wu LQ et al (2006) Morphologic, phenotypic and functional characteristics of endothelial cells derived from human hepatic cavernous hemangioma. J Vasc Res 43:522-532 